\title{
HUBUNGAN PEMBERIAN MAKANAN PENDAMPING ASI (MP-ASI) DENGAN STATUS GIZI BAYI USIA 0-6 BULAN DI DESA LINGGAJAYA KECAMATAN CIWARU KABUPATEN KUNINGAN
}

\author{
${ }^{1}$ Mala Tri Marliana, ${ }^{2}$ Anggit Kartikasari, ${ }^{3}$ Ana Ameliyani Solihah
}

Sekolah Tinggi Ilmu Kesehatan Kuningan

malamarliana29@gmail.com

\begin{abstract}
Abstrak
Pemberian makanan pendamping ASI (MP-ASI) dapat mempengaruhi status gizi bayi secara langsung. setelah bayi berusia 6 bulan MP-ASI perlu mulai diperkenalkan pada bayi. Namun pada kenyataannya masih ada beberapa orang tua yang sudah memberikan MP-ASI lebih dini kurang dari uasia 6 bulan. Bayi dengan usia kurang dari 6 bulan sistem pencernaannya belum sempurna untuk menerima makanan padat karena pencernaan bayi tidak akan tercerna dengan baik sehingga dapat menyebabkan reaksi yang tidak diharapkan seperti gangguan pencernaan, konstipasi dan timbulnya gas). maka dari itu sebaiknya bayi yang berusia kurang dari 6 bulan seharusnya tidak diberikan Makanan Pendamping ASI terlebih dahulu. Tujuan dari penelitian ini adalah untuk mengetahui adakah hubungan antara pemberian MP-ASI dengan status gizi bayi usia 0-6 bulan. Metode penelitian yang digunakan analitik dengan cross sectional, menggunakan instrument kuesioner, timbangan dan tabel WHO-NCHS. Analisis dalam penelitian ini menggunakan Rank Spearman. Populasi dalam penelitian ini adalah ibu menyusui sebanyak 45 responden dengan teknik total sampling. Hasil analisis bivariat menunjukkan nilai p (0.003) atau < $(0.05)$ hal ini menunjukkan bahwa terdapat hubungan antara pemberian MP-ASI dengan status gizi bayi usia 0-6 bulan. Kesimpulannya terdapat hubungan pemberian MP-ASI dengan status gizi bayi usia 0-6 bulan.
\end{abstract}

Kata Kunci: MP-ASI, Status Gizi.

\section{Pendahuluan}

Pemberian Air Susu (ASI) yang diberikan sejak dini menjadi modal dasar untuk membentuk manusia yang berkualitas. Konferensi hak-hak anak tahun 1990 antara lain menegaskan bahwa salah 
JOURNAL OF MIDWIFERY CARE :

VOL. 01 NO. 02, JUNI 2021

DOI : $\underline{10.34305 / j m c . v 1 i 02.303}$
Ciptaan disebarluaskan di bawah

Lisensi Creative Commons Atribusi-

NonKomersial-BerbagiSerupa 4.0 satu faktor yang dapat mempengaruhi pertumbuhan dan perkembangan anak adalah ASI, dengan demikian ASI harus dipenuhi oleh orang tuanya dimana ASI menjadi hak asasi bayi.

Makanan terbaik bagi bayi adalah ASI sebagai makanan alamiah yang diberikan oleh seorang ibu kepada anak yang dilahirkannya. ASI mengandung zat perlindungan yang dapat menghindari berbagai penyakit infeksi terhadap bayi, selain dari fungsi komposisinya untuk pertumbuhan pada bayi. Pemberian ASI juga mempengaruhi tingkat emosional yang sangat dapat mempengaruhi hubungan batin antara ibu dan anak.

Badan Kesehatan Dunia (WHO) dan Badan Perserikatan Bangsa-Bangsa (PBB) yang mendanai program anak-anak (United Nations Children's) menetapkan bahwa pemberian ASI secara ekslusif selama 6 bulan pada bayi. Dalam hal ini sudah jelas bahwa bayi hanya mendapatkan hanya ASI saja selama 6 bulan tanpa mendapatkan makanan atau minuman. Penelitian menunjukan, bahwa bayi yang hanya mendapatkan ASI saja selama 6 bulan akan mendapatkan banyak manfaat. ASI sudah dirancang khusus untuk bayi tidak akan ada yang bisa menggantikan ASI.

Setelah berusia 6 bulan bayi mulai dikenalkan dengan makanan pendamping ASI secara bertahap sesuai dengan usia. Namun ditemukan fakta bahwa masih adanya orangtua yang memberikan makanan pendamping ASI yang terlalu dini ataupun terlambat (Sulistijani \& Herlianty, 2006).

Pemberian makanan pendamping ASI terlalu dini dapat menimbulkan gangguan pada pencernaan seperti diare. Bayi dengan usia kurang dari 6 bulan sistem pencernaannya belum sempurna untuk menerima makanan padat karena pencernaan bayi tidak akan tercerna dengan baik sehingga dapat menyebabkan reaksi yang tidak diharapkan seperti gangguan pencernaan, konstipasi dan timbulnya gas). maka dari itu sebaiknya bayi yang berusia kurang dari 6 bulan seharusnya tidak diberikan Makanan Pendamping ASI terlebih dahulu. Begitupun sebaliknya jika makanan padat diberikan terlalu terlambat dapat mengakibatkan kesulitan untuk belajar mengunyah pada bayi dan bayi tidak akan menyukai makanan padat sehingga bayi 
JOURNAL OF MIDWIFERY CARE :

VOL. 01 NO. 02, JUNI 2021

DOI : $\underline{10.34305 / j m c . v 1 i 02.303}$

dapat menjadi kekurangan gizi

(Prasetyono, 2012).

MP-ASI merupakan salah satu faktor yang mempengaruhi status gizi bayi. MP-ASI adalah makanan atau minuman mengandung zat gizi yang diberikan kepada bayi atau anak usia 6-24 bulan untuk dapat memenuhi kebutuhan gizi selain ASI. Di masyarakat yang terjadi menunjukkan bahwa pemberian MP-ASI diberikan pada bayi yang masih berumur kurang dari 6 bulan. Penjelasan MP-ASI dan status gizi balita dapat menyebabkan status gizi kurang bahkan sampai status gizi buruk yang disebabkan dari aspek sebab akibat pemberian MP-ASI yang kurang tepat (Deba, 2007).

Penelitian yang dilakukan Jane et.al 2009 di Perth, Australia menerangkan bahwa $44 \%$ bayi berusia kurang dari 17 minggu sudah diberikan makanan padat. Beberapa hasil penelitian lain menunjukkan bahwa bayi berusia sebelum 4 bulan sudah diberikan makanan padat diantaranya, Selandia Baru (45\%), Finlandia (63\%) dan (70\%) Kanada. Bahkan dari penelitian di Skotlandia menunjukan bahwa $40 \%$ bayi berusia 12 minggu sudah diberikan makanan padat.
Ciptaan disebarluaskan di bawah

Lisensi Creative Commons Atribusi-

NonKomersial-BerbagiSerupa 4.0 Internasional.
Berdasarkan hasil penelitian yang telah dilakukan oleh Widodo tahun 2001 di provinsi Jawa Tengah dan Jawa Barat terdapat sebanyak $77 \%$ responden yang telah memberikan makanan prelaktal dan $23 \%$ responden hanya memberikan ASI saja kepada bayinya. Di Jawa Barat jumlah bayi usia 0-6 bulan yang diberikan ASI ekslusif sebesar 25,8\% pada tahun 2001 (Widodo, 2001). Kabupaten Kuningan untuk bayi berusia 0-6 bulan sebesar 36,2 $\%$ yang mendapat ASI dan 54,8\% telah diberikan MP-ASI (Dinas Kesehatan Kuningan, 2011) Kecamatan Ciwaru pemberian ASI Eksklusif pada bayi 0-6 bulan sebesar $14,4 \%$ dan selebihnya yang telah diberikan MP-ASI yaitu sebesar $85,6 \%$ (UPTD Puskesmas, 2016). Pemantauan status gizi berdasarkan indeks berat badan per usia, menunjukkan bahwa gizi baik $(79,7 \%)$, gizi kurang $(14,9 \%)$, gizi buruk $(3,8 \%)$, dan gizi lebih $(1,5 \%)$. Status gizi balita berdasarkan indeks tinggi badan per usia, menunjukkan bahwa normal $(71 \%)$ dan balita pendek dan sangat pendek $(29,9 \%)$. Status gizi balita berdasarkan indeks berat badan per tinggi badan menunjukkan hasil normal $(82,7 \%)$, kurus $(8,2 \%)$, gemuk $(5,3 \%)$, dan sangat kurus $(3,7 \%)$ (Kementerian Kesehatan RI, 
JOURNAL OF MIDWIFERY CARE :

VOL. 01 NO. 02, JUNI 2021

DOI : $\underline{10.34305 / j m c . v 1 i 02.303}$

2015). Di Indonesia sebagian besar status gizi sudah baik, namun masih ditemukan beberapa bayi yang memiliki gangguan status gizi dengan gizi buruk, gizi kurang dan bahkan ada yang memiliki status gizi lebih. Di wilayah kerja Puskesmas Ciwaru yang menunjukkan tingginya pemberian MP-ASI secara dini sebanyak 70,15\% dengan status gizi kurang sebanyak $11,51 \%$.

Studi pendahuluan yang telah dilakukan oleh penulis dengan cara wawancara di Desa Linggajaya terdapat 7 dari 10 bayi usia 0-6 bulan (70\%) telah diberikan MP-ASI dan ditemukan satu orang bayi yang menderita gizi kurang, sebagai akibat dari pemberian makanan yang lebih awal yaitu sebelum bayi berumur 6 bulan. Berdasarkan uraian tersebut penulis tertarik untuk melakukan penelitian dengan judul "Pemberian Makanan Pendamping ASI (MP-ASI) dengan status gizi bayi (0-6 bulan)".

\section{Metode}

Penelitian menggunakan jenis penelitian analitik dengan pendekatan cross sectional. Penelitian ini dilakukan di Desa Linggajaya Kecamatan Ciwaru kabupaten Kuningan, menggunakan data primer berupa kuesioner, timbangan dan tabel WHO-NCHS. Populasi dalam penelitian ini adalah seluruh ibu menyusui yang memiliki bayi usia 0-6 bulan yang berdomisili di Desa Linggajaya Kecamatan Ciwaru berjumlah 45 responden. Sampel dalam penelitian ini adalah seluruh ibu menyusui yang memiliki bayi usia 0-6 bulan yang berdomisili di Desa Linggajaya berjumlah 45 responden. Teknik sampling menggunakan total sampling. Instrumen yang digunakan adalah kuesioner dan analisis yang digunakan analisis univariat dan bivariat dengan menggunakan uji statistik Rank Spearman.

\section{Hasil}

Analisis univariat dalam penelitian ini dimaksudkan untuk mengetahui gambaran distribusi frekuensi pemberian makanan pendamping ASI (MP-ASI) dan status gizi bayi usia 0-6 bulan. 
Tabel 1. Distribusi Pemberian MP-ASI dan Status Gizi Bayi (n=45)

\begin{tabular}{lcc}
\hline \multicolumn{1}{c}{ Variabel } & F & \% \\
\hline Pemberian MP-ASI & & \\
Tidak diberikan & 13 & 28,9 \\
Diberikan & 32 & 71,1 \\
\hline Status Gizi & 2 & \\
Gizi Buruk & 2 & 4,4 \\
Gizi Kurang & 14 & 60 \\
Gizi Baik & 27 & 4,4 \\
Gizi Lebih & 2 & \\
\hline
\end{tabular}

Berdasarkan tabel 1 Pemberian MP-ASI sebagian besar telah diberikan MP-ASI sebanyak 71,1\%, sebagian besar status gizi bayi usia 0-6 bulan yang paling banyak yaitu gizi baik sebesar $60 \%$.
Anaslisis bivariat digunakan untuk mengetahui hubungan antara pemberian MP-ASI dengan status gizi bayi usia 0-6 bulan dapat dilihat pada tabel berikut:

Tabel 2. Hubungan Pemberian MP-ASI dengan Status Gizi Bayi (n=45)

\begin{tabular}{|c|c|c|c|c|c|c|c|c|c|c|c|}
\hline \multirow{3}{*}{ Pemberian MP-ASI } & \multicolumn{8}{|c|}{ Status Gizi } & \multirow{2}{*}{\multicolumn{2}{|c|}{ Total }} & \multirow{3}{*}{ P-value } \\
\hline & \multicolumn{2}{|c|}{ Buruk } & \multicolumn{2}{|c|}{ Kurang } & \multicolumn{2}{|c|}{ Baik } & \multicolumn{2}{|c|}{ Lebih } & & & \\
\hline & f & $\%$ & f & $\%$ & f & $\%$ & f & $\%$ & $\mathbf{F}$ & $\%$ & \\
\hline Tidak diberikan & 0 & 0 & 1 & 7,7 & 10 & 76,9 & 2 & 15,4 & 13 & 100 & \\
\hline Diberikan & 2 & 6,2 & 13 & 40,7 & 17 & 53,1 & 0 & 0 & 32 & 100 & \\
\hline
\end{tabular}

Dari tabel 2 dapat diketahui bahwa dari 32 responden yang memberikan MPASI hampir separuhnya berstatus gizi baik yaitu sebanyak 17 orang $(53,1 \%)$ dan responden yang tidak memberikan MPASI sebagian besar berstatus gizi baik sebesar 10 orang $(76,9 \%)$ dengan nilai $\mathrm{p}$ value $=(0.003)$ atau $<(0.05)$ sehingga dapat dijelaskan bahwa terdapat hubungan antara pemberian MP-ASI dengan status gizi bayi usia 0-6 bulan.
Berdasarkan hasil menunjukkan bahwa terdapat hubungan antara pemberian Makanan Pendamping ASI (MP-ASI) dengan status gizi bayi usia 0-6 bulan dengan nilai $\mathrm{p}(0.003)$. Dari hasil uji korelasi antara pemberian MP-ASI dengan status gizi bayi usia 0-6 bulan di desa Linggajaya kecamatan Ciwaru dapat dilihat bahwa sebagian besar bayi diberikan MP-ASI usia <6 bulan dengan status gizi baik. Hal ini dikarenakan 
JOURNAL OF MIDWIFERY CARE :

VOL. 01 NO. 02, JUNI 2021

DOI : $\underline{10.34305 / j m c . v 1 i 02.303}$

pemberian ASI masih dominan dibandingkan pemberian MP-ASI.

\section{Pembahasan}

Status gizi bayi dipengaruhi oleh pemberian MP-ASI yang menimbulkan dampak kesehatan jika tidak sesuai dengan umur dan kebutuhannya. Dalam siklus hidup manusia gizi memegang peranan yang sangat penting sehingga bayi yang mengalami kekurangan gizi jika tidak diatasi sejak dini akan berlanjut hingga dewasa nantinya. Pada periode emas dikatakan periode kritis yaitu usia 0-24 bulan adalah masa pertumbuhan dan perkembangan yang sangat pesat (Yuliarti, 2010).

Pada periode emas ini dapat kita wujudkan untuk tumbuh kembang yang optimal jika pada masa ini asupan gizi pada bayi dan anak diperoleh sesuai dengan kebutuhannya dan sebaliknya jika bayi dan anak tidak mendapatkan gizi yang sesuai dengan kebutuhannya maka periode emas ini tidak akan terwujud dengan optimal akan tetapi berubah menjadi periode kritis yang nantinya akan mengganggu proses pertumbuhna dan perkembangan hingga masa selanjutnya.
Ciptaan disebarluaskan di bawah

Lisensi Creative Commons Atribusi-

NonKomersial-BerbagiSerupa 4.0

Internasional.

\section{(c) (i) (5)}

Berdasarkan hasil penelitian menyatakan bahwa faktor penyebab status gizi bayi dan anak diantaranya disebabkan pemberian MP-ASI yang tidak tepat, baik secara kualitas maupun kuantitasnya (Ariani, 2008). Kematangan saluran cerna, kematangan mekanisme menelan pada bayi dan pertumbuhan gigi terjadi pada usia 4-6 bulan, berdasarkan alasan tersebut sesuai dengan yang dianjurkan oleh WHO bahwa MP-ASI pada usia 6 bulan dapat diberikan pada waktu yang paling cepat (Damayanti, 2007).

Hal ini sejalan dengan penelitian yang dilakukan Wahyuningsih (2013), bahwa usia pertama pemberian MP-ASI pada bayi umur 0-12 bulan sebagian besar diberikan MP-ASI dini sebanyak 52 bayi $(71,2 \%)$ dan status gizi bayi sebagian besar dengan status gizi normal berjumlah 60 bayi $(91,5 \%)$. Hal ini dikarenakan usia pertama pemberian MP-ASI bukan merupakan faktor utama yang mempengaruhi status gizi bayi. Asupan makanan yang diterima oleh bayi merupakan salah satu faktor yang paling mempengaruhi status gizi bayi (Wahyuningsih, n.d.).

Menurut asumsi peneliti beberapa faktor yang dapat mempengaruhi ibu 
JOURNAL OF MIDWIFERY CARE :

VOL. 01 NO. 02, JUNI 2021

DOI : $\underline{10.34305 / j m c . v 1 i 02.303}$
Ciptaan disebarluaskan di bawah

Lisensi Creative Commons Atribusi-

NonKomersial-BerbagiSerupa 4.0

Internasional. dalam pemberian MP-ASI diantarnya adalah pengalaman ibu, sosial budaya, umur ibu, pendidikan ibu, pekerjaan ibu, dukungan keluarga dan keterpaparan media. Sehingga pemberian ASI ekslusif selama 6 bulan belum optimal karena ibu sudah memberikan MP-ASI pada bayinya yang berusia $<6$ bulan. MP-ASI yang diberikan berupa pisang yang dilumatkan dan bubur tepung. Namun status gizi bayi pada usia 0-6 bulan di Desa Linggajaya yang paling banyak status gizi baik meskipun pemberian MP-ASI tidak sesuai dengan umurnya. Hal ini dikarenakan pemberian MP-ASI yang jarang karena ibu lebih dominan memberikan bayinya ASI daripada MP-ASI. Ibu beralasan bahwa MP-ASI yang diberikan pada bayinya hanya untuk menambah gizi bayi yang dirasa kurang dalam pemberian ASI, biasanya ibu memberikan MP-ASI pada siang hari.

Pemberian MP-ASI berarti memberikan makanan lain sebagai pendamping ASI yang diberikan bayi dan anak usia 6-24 bulan. Bayi dan anak dapat tumbuh secara optimal jika MP-ASI diberikan dengan baik dan tepat sehingga dapat memenuhi kebutuhan gizi yang dibutuhkan oleh bayi dan anak. Cara pemberian MP-ASI diberikan sesuai dengan tahapan usianya, dimulai dari MPASI berstruktur lumat, lembek dampai nantinya anak akan terbiasa dengan makanan keluarga. Di samping MP-ASI pemberian ASI dilanjutkan sebagai zat gizi dan faktor pelindung penyakit hingga anak mencapai usia 2 tahun.

\section{Kesimpulan}

Berdasarkan hasil penelitian ini dapat disimpulkan bahwa terdapat hubungan antara pemberian MP-ASI dengan status gizi bayi usia 0-6 bulan. bayi akan memiliki berat badan kurang dan juga akan terhambat pertumbuhannya jika diberikan MP-ASI < 6 bulan karena dari sisi lain bayi masih menyusu sehingga sebagian zat gizi esensial diperoleh dari ASI.

\section{Daftar Pustaka}

Ariani. (2008). Makanan Pendamping ASI.

Damayanti, R. S. (2007). Kapan Mulai Memberi Makanan Pendamping ASI. http://www.sahabatnestle.co.id/homev 2/main/infant $/$ main.asp?page $=$ articl\&i $\mathrm{d}=1379$

Deba, U. (2007). Perbedaan Status Gizi Antara Bayi Yang Diberi ASI Eksklusif Dengan Bayi Yang Diberi MP-ASI Dini Di Puskesmas 
JOURNAL OF MIDWIFERY CARE :

VOL. 01 NO. 02, JUNI 2021

DOI : $\underline{10.34305 / \text { jmc.v1i02.303 }}$

Perumnas Kota Kendari. Jurnal SELAMI IPS, 2, 21.

Dinas Kesehatan Kuningan. (2011). Laporan Pemberian MP-ASI.

Kementerian Kesehatan RI. (2015). Kementerian Kesehatan Republik Indonesia.

http://www.depkes.go.id/resources/do wnload/info-publik/Renstra-2015.pdf

Prasetyono, D. (2012). Buku Pintar ASI Ekslusif. DIVA Press.

Sulistijani, D., \& Herlianty. (2006). Menjaga Kesehatan Bayi Dan Balita. Puspa Swara.

UPTD Puskesmas. (2016). Laporan Bulanan ASI Ekslusif bulan Januari-
Ciptaan disebarluaskan di bawah Lisensi Creative Commons Atribusi-

NonKomersial-BerbagiSerupa 4.0 Internasional.

November.

Wahyuningsih, R. (n.d.). Hubungan Usia Pertama Pemberian Makanan Pendamping ASI dengan Status Gizi Bayi Usia 0-12 Bulan di Kelurahan Karangjati Kecamatan Bergas Kabupaten Semarang. 2013.

Widodo, Y. (2001). Kebiasaan Memberikan Makanan Kepada Bayi Baru Lahir Di Propinsi Jawa Tengah Dan Jawa Barat (New Born Infant Feeding Habit in Central Java and West Java). Media Penelitian Dan Pengembangan Kesehatan, 11(3), 150847.

Yuliarti, N. (2010). Keajaiban ASI. CV. Andi. 